\title{
Cytotoxic activity in cutaneous leishmaniasis
}

\author{
Taís M Campos ${ }^{1,2}$, Rúbia Costa ${ }^{1,2}$, Sara Passos ${ }^{1,3}$, Lucas P Carvalho Cr, $^{1,4,5} /+$ \\ ${ }^{1}$ Universidade Federal da Bahia, Serviço de Imunologia, Salvador, BA, Brasil \\ ${ }^{2}$ Universidade Federal da Bahia, Faculdade de Medicina da Bahia, Programa de Pós-Graduação em Ciências da Saúde, Salvador, BA, Brasil \\ ${ }^{3}$ Houston Methodist Research Institute, Department of Nanomedicine, Houston, TX, United States \\ ${ }^{4}$ Instituto Nacional de Ciências e Tecnologia-Doenças Tropicais, Salvador, BA, Brasil \\ ${ }^{5}$ Fundação Oswaldo Cruz-Fiocruz, Instituto Gonçalo Moniz, Laboratório Avançado de Saúde Pública, Salvador, BA, Brasil
}

Cutaneous leishmaniasis (CL) is a chronic disease caused by species of the protozoan Leishmania and characterised by the presence of ulcerated skin lesions. Both parasite and host factors affect the clinical presentation of the disease. The development of skin ulcers in CL is associated with an inflammatory response mediated by cells that control parasite growth but also contribute to pathogenesis. CD8+ T cells contribute to deleterious inflammatory responses in patients with CL through cytotoxic mechanisms. In addition, natural killer cells also limit Leishmania infections by production of interferon- $\gamma$ and cytotoxicity. In this review, we focus on studies of cytotoxicity in CL and its contribution to the pathogenesis of this disease.

Key words: cytotoxicity - CD8+ T cells - NK cells - cutaneous leishmaniasis - immunopathology

The outcome of cutaneous leishmaniasis (CL) depends on the infecting parasite species and the type and intensity of the immune response to that parasite (Barral Netto et al. 1998, Castellano et al. 2009, Kaye \& Scott 2011). The coordinated action of innate and adaptive immune responses is fundamental for protection against Leishmania (Gorak et al. 1998). As cells in the innate response, natural killer (NK) cells represent an important line of defence against these parasites, acting as the main source of interferon (IFN)- $\gamma$ early in infection and thus contributing to the activation of macrophages to kill Leishmania (Gorak et al. 1998). Susceptibility or resistance to disease is associated with responses mediated by $\mathrm{T}$ lymphocytes (CD4+ and CD8+) (Scott et al. 1988) that produce cytokines such as tumour necrosis factor (TNF) and INF- $\gamma$, which are important to controlling Leishmania infections (Pirmez et al. 1993, Da-Cruz et al. 2002). Moreover, these cells mediate effector mechanisms to fight infections, not only through the secretion of cytokines and chemokines but also through cytotoxic activity that induces apoptosis of infected cells (Ruiz \& Becker 2007). Conversely, some studies have shown the contribution of cytotoxic activity to skin ulcer development in patients with CL. Here, we discuss recent literature defining the contribution of cytotoxic cells to the pathogenesis of CL.

Cytotoxic activity and pathogenesis of $C L-C L$ is caused by several different species of Leishmania protozoan parasites, and both parasite and host factors affect the clinical spectrum of the disease (Barral Netto et al. 1998, Castellano et al. 2009, Schriefer et al. 2009). At an early stage of infection, neutrophils are recruited rapidly

doi: 10.1590/0074-02760170109

Financial support: National Institutes of Health (grant U01 Al088650-06)

+ Corresponding author: carvalholp76@gmail.com

Received 16 March 2017

Accepted 10 July 2017 to the site of inoculation, where they capture Leishmania and produce reactive oxygen species and elastase (Peters et al. 2008, Thalhofer et al. 2011, Falcão et al. 2015). Neutrophils also release cytokines such as TNF and chemokines and interact with mononuclear phagocytes, contributing to both resistance and susceptibility to Leishmania infections (Scapini et al. 2000, RibeiroGomes et al. 2004, 2007, 2012, Novais et al. 2009). In addition to neutrophils, mononuclear phagocytes interact with Leishmania early in infection, playing a pivotal role in promoting resistance to the parasite, mainly through the production of IL-12 that leads to differentiation of naïve $\mathrm{CD} 4+\mathrm{T}$ cells into Th1-type T cells. IL12 is also important in inducing IFN- $\gamma$ secretion by NK cells, which can promote the destruction of Leishmania through a cytotoxic mechanism (Gorak et al. 1998, Lemos et al. 2004). Although Leishmania parasites reside within parasitophorous vacuoles in mononuclear phagocytes, their antigens are presented via MHC class I to CD8+ T cells, which contributes to a Th1 environment through the production of TNF and IFN- $\gamma$ (Pirmez et al. 1993, Da-Cruz et al. 2002, D’Oliveira Jr et al. 2002, Jordan \& Hunter 2010). Moreover, cytotoxic activity by $\mathrm{CD} 8+\mathrm{T}$ cells is important to parasite elimination (Khan et al. 1990, Da-Cruz et al. 1994, Barral Netto et al. 1995, Montoya et al. 1996, Purner et al. 1996, Jordan \& Hunter 2010). While cytotoxic activity induces target cell death, cytokines such as IFN- $\gamma$ and TNF participate in the development of an inflammatory response that modulates macrophage and dendritic cell activity; however, when these pathways are not properly regulated, inflammatory disorders and tissue damage can develop (Ribeiro-de-Jesus et al. 1998, Follador et al. 2002, Arias et al. 2014). This is the scenario observed in patients with CL: after Leishmania infection, most patients develop lymphadenopathy, followed by the appearance of a papule at the bite site (Barral et al. 1992, 1995), with higher parasite load (Saldanha et al. 2017). In a few days, the papule becomes an ulcerated lesion characterised by 
intense inflammatory infiltration, with presence of $\mathrm{T}$ and B lymphocytes, mononuclear phagocytes, plasma cells (Pirmez et al. 1993, Da-Cruz et al. 2002), and a few parasites (Ribeiro-de-Jesus et al. 1998, Bacellar et al. 2002, Gaze et al. 2006, Saldanha et al. 2017). High levels of the proinflammatory cytokine TNF has been detected in the biopsies of patients with CL (Antonelli et al. 2005). This cytokine contributes to the destruction of Leishmania but also induces cellular adhesion, necrosis, and cytotoxicity, thereby contributing to disease pathogenesis (Ribeiro-de-Jesus et al. 1998, Bacellar et al. 2002, Da-Cruz et al. 2002). In this sense, CD8+ T cells and NK cells participate in the immune response to Leishmania braziliensis, not only contributing to TNF production but also showing cytotoxic activity. Machado et al. (2002) observed CD8+ T cells and NK cells and their cytotoxic activities in lesions of patients with CL, suggesting not only the active participation of these cells in parasite destruction but also their role in ulceration. IL-10 is the main regulatory cytokine in this immune response, and despite of the presence of IL-10 in ulcers of CL and mucosal leishmaniasis (Tomlinson et al. 2008) cases, low levels of expression of its receptor have been documented and associated with a high frequency of activated CD4+ and CD8+ T cells (Bacellar et al. 2002, Faria et al. 2005, Gaze et al. 2006, Carvalho et al. 2007).

Recent work has shown that cytotoxicity is one of the main mechanisms underlying disease induced by L. braziliensis infection (Faria et al. 2009, Dantas et al. 2013, Novais et al. 2013, 2015, Santos et al. 2013, 2015, Cardoso et al. 2015, Ferraz et al. 2015, 2017) (Table). In a recent study performed by our group, we compared gene expression in lesions of patients with CL with that in normal skin from healthy individuals. Genes associated with cytolysis, such granzyme B, granzyme A, and granulysin, were highly expressed in CL lesions when compared to normal skin. This study revealed a significant enrichment in the activity of pathways involved in NK cell-mediated cytotoxicity in CL lesions (Novais et al. 2013). Interestingly, we also found that NK cell cytolytic pathways activated in CL lesions were greatly enriched when compared to those in skin lesions of patients with psoriasis, suggesting that cytolysis is a pathological characteristic associated with skin ulcers but not skin inflammatory plaques. Another transcriptional analysis of lesions showed that early non-ulcerated papular lesions from CL individuals had a similar transcriptional profile to that of ulcerated lesions, indicating that the pathological response occurs very soon after infection in patients with CL (Novais et al. 2015). These results suggest that cytotoxicity is one of the main mechanisms of immunopathology in CL, rather than being a consequence of pathology.

Cytotoxic activity is shown by a variety of immune cells, including CD8+ T, NK, and NKT cells, that destroy targets through the release of cytotoxic granules containing preforin and granzymes. Perforin promotes pore formation in target cell membranes, facilitating the entry of granzymes and inducing programmed cell death through DNA fragmentation (Trapani 2001, Tra- pani \& Smyth 2002, Pipkin \& Lieberman 2007, Ruiz $\&$ Becker 2007). Cell death can occur through the activation of apoptotic cysteine proteases (caspases) or in the absence of their activation (Waterhouse et al. 2006, Pipkin \& Lieberman 2007, Hoves et al. 2010). Activation of the mitochondrial pathway by granzyme B-inducing cell death mechanisms has been observed in CL lesions, and a positive correlation between the expression of caspase-3 and caspase- 9 , as well as caspase- 9 and granzyme $\mathrm{B}$, was observed in individuals with these lesions (Santos et al. 2015). The caspase pathway is also associated with lesion progression, with a positive correlation between the expression of caspase-3, caspase- 9 , and granzyme B proteins and lesion size in patients with CL (Santos et al. 2015). Although the effect of cytotoxic mechanisms is the destruction of target cells, CD8+ T cell cytotoxicity does not control L. braziliensis parasites (Santos et al. 2013). Santos et al. (2013) found that CD8+ T cells in co-culture with Leishmania-infected macrophages released granzyme B but had no effect on parasite killing, whereas $\mathrm{CD} 4+\mathrm{T}$ cells in co-culture with infected macrophages produced IFN- $\gamma$ and mediated Leishmania killing. Additionally, an association between lesion size and the presence of cytotoxic cells has been documented in L. braziliensis infections. Faria et al. (2009) reported that the frequency of $\mathrm{CD} 8+\mathrm{T}$ cells expressing granzyme is directly associated with the intensity of inflammation in ulcers of patients with CL. Furthermore, patients with ulcerated CL lesions have a higher frequency of these cells than patients in the initial phase of infection, indicating the participation of $\mathrm{CD} 8+\mathrm{T}$ cells in disease progression. A histopathological analysis of fragments of lesions from patients with early CL, late CL, and disseminated leishmaniasis (DL) showed the presence of CD8+ granzyme $\mathrm{B}+$ lymphocytes in the papillary dermis. Further, an evaluation of cytotoxic activity in inflammatory infiltrates revealed that new lesions (those with less than 20 days of development) had fewer cells expressing granzyme B than late ulcers and ulcers from patients with DL (Dantas et al. 2013). Taken together, these data suggest that cytotoxic activity of $\mathrm{CD} 8+\mathrm{T}$ cells and granzyme B production can lead to injury of the basal membrane layer, contributing to ulcer formation and disease progression.

Some individuals residing in areas with L. braziliensis transmission do not have a history of leishmaniasis but are Leishmania skin test-positive but have no symptoms (Follador et al. 2002). The ratio of infection to disease in one CL endemic area in northeastern Brazil is 3.7:1 (Unger et al. 2009). An evaluation of the cytotoxic activity of $\mathrm{CD} 8+\mathrm{T}$ cells in sub-clinical infections and patients with CL showed that CD8+ T cells in individuals with CL induced apoptosis of more infected monocytes than CD8+ $\mathrm{T}$ cells from sub-clinically infected subjects, and the production of granzyme $\mathrm{B}$ in CD8+ $\mathrm{T}$ cells was higher in individuals with $\mathrm{CL}$ than in those with sub-clinical infection (Cardoso et al. 2015). This suggests that cytotoxic activity of CD8+ T cells in patients with CL can contribute to pathology, because subjects with sub-clinical infections do not develop lesions. 


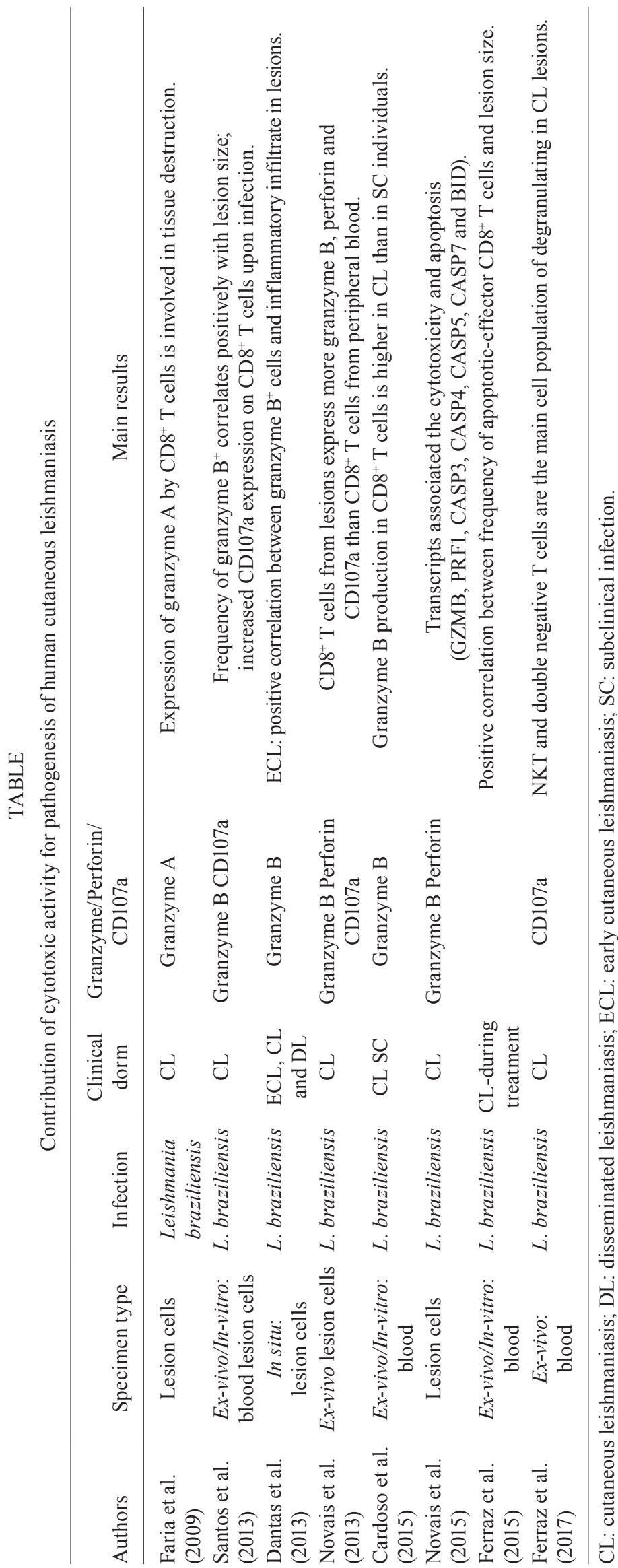


To date, the mechanisms underlying cytotoxicity-induced tissue damage in CL are not well understood; however, a few studies have demonstrated the participation of cytolytic molecules in deleterious immune responses to L. braziliensis infection. Lytic granules of cytotoxic lymphocytes are composed of secretory lysosomes with a dense centre of granzyme and perforin proteins (Trapani \& Smyth 2002, Thiery et al. 2011). This centre is covered with a lipid bilayer composed of lysosomal-associated membrane protein 1 (LAMP-1), also known as CD107a (Betts et al. 2003). Tissue from CL lesions cultured with L. braziliensis parasites showed an increase in CD107a expression relative to that of non-infected control tissue from the same lesion (Santos et al. 2013). Furthermore, this study demonstrated the localisation of CD8+ T cells and granzyme $\mathrm{B}$ in biopsied tissue from patients and a positive correlation between the amounts of CD8+ T cell granzyme B+ and lesion size (Santos et al. 2013). We also showed that $\mathrm{CD} 8+\mathrm{T}$ cells from $\mathrm{CL}$ lesions express CD107a, whereas CD8+ T cells from the blood of patients with CL do not express this protein (Novais et al. 2013). Another mechanism underlying cytotoxicity that does not depend on MHC class I antigen presentation is the engagement of NKG2D, which is present in a variety of cells, including CD8+ T cells and NK/NKT cells.

Although several cell types are cytotoxic, few studies have shown the contribution of cells other than CD8+ T cells in cytolysis in Leishmania. Cytotoxic activity of NK cells is initiated after recognition of ligands present on target cells by the receptors NKp30, NKp44, NKp46, and NKG2D, with the latter expressed by CD8+ T cells (Watzl 2003, Lanier 2005). Studies on NK cells have shown that the most abundant surface glycoprotein on Leishmania, gp63, inhibits human NK cell proliferation and decreases expression of NKp30, NKp44, and CD16 (Lieke et al. 2008). In contrast, Leishmania lipophosphoglycan (LPG) activates NK cells via Toll-like receptor 2, leading to the production of the proinflammatory cytokines IFN- $\gamma$ and TNF (Becker et al. 2003). The recognition of LPG by NK cells was also shown to lead to promastigote lysis, but to destroy NK cells in a non-apoptotic manner (Lieke et al. 2011). Recently, Naouar et al. (2014) evaluated the cytotoxic immune responses of cells from individuals with previous contact with Leishmania major. They observed that $\mathrm{CD} 4+\mathrm{T}$ cell subsets produced granzyme $\mathrm{B}$ in response to L. major antigens. Although this result suggests a cytotoxic role for CD4+ T cells, cytolysis was not assessed in these experiments. Previous studies have shown that the main role of CD4+ T cells in L. braziliensis infections is IFN- $\gamma$ production for parasite killing (Kaye \& Scott 2011, Santos et al. 2013). Ferraz et al. (2017) evaluated the frequency of degranulating cell subsets in CL lesions and found that NKT cells and double-negative $\mathrm{T}$ cells $(\mathrm{CD} 3+\mathrm{CD} 4-\mathrm{CD} 8-)$ displayed a higher frequency of CD107a than did CD8+ T cells.

Mechanisms other than cell death by apoptosis, such as excessive degradation of the extracellular matrix (ECM), may also indirectly contribute to leishmaniasis pathology. (Costa et al. 2008, Maretti-Mira et al. 2011a, b, Campos et al. 2014). Granzymes have been shown to activate pro-inflammatory cytokines and degrade multiple com- ponents of the ECM (Hiebert \& Granville 2012). Treatment of epithelial cells, fibroblasts, or monocytes with purified human granzyme A resulted in the production of pro-inflammatory cytokines such as IL-1 $\beta$, IL-6, IL-8, and TNF in a process that may be dependent on caspase-1 (Sower et al. 1996, Metkar et al. 2008). Granzyme B can indirectly promote inflammation through the activation of cytokines such as IL-18, IL-1 $\beta$, and IL-1 $\alpha$ (Omoto et al. 2010, Afonina et al. 2011, Hiebert \& Granville 2012). One likely explanation of how cytotoxic cells mediate inflammation and tissue injury in CL is that, after degranulation of cytotoxic cells, granzyme B and perforin are released into the extracellular space, inducing apoptosis of infected macrophages and bystander cells. Additionally, extracellular granzyme B may indirectly induce inflammation through the activation of pro-inflammatory cytokines and degradation of ECM substrates, contributing to tissue injury (Figure). These data suggest a role for granzymes in amplifying inflammation in Leishmania infections and thus contributing to tissue damage. However, additional functional studies must be performed to elucidate the role of granzymes in human cases of CL.

Cytotoxic activity in experimental models of $C L$ Mouse models have been used to study many aspects of innate and adaptive immune responses to various Leishmania species. Initially, CD8+ T cells were associated with protection and cure of leishmaniasis, as studies using experimental models of leishmaniasis showed that $\mathrm{CD} 8+$ cells were required for a primary immune response against L. major infection (Titus et al. 1987, Hill et al. 1989, Muller et al. 1991). Later, these data were contradicted, when mice deficient in CD8 or $\beta 2$ microglobulin were shown capable of resolving primary L. major infection (Overath \& Harbecke 1993, Wang et al. 1993, Huber et al. 1998). A few years later, a protective response induced by CD8+ T cells was again suggested in models of infection with a low dose of L. ma-

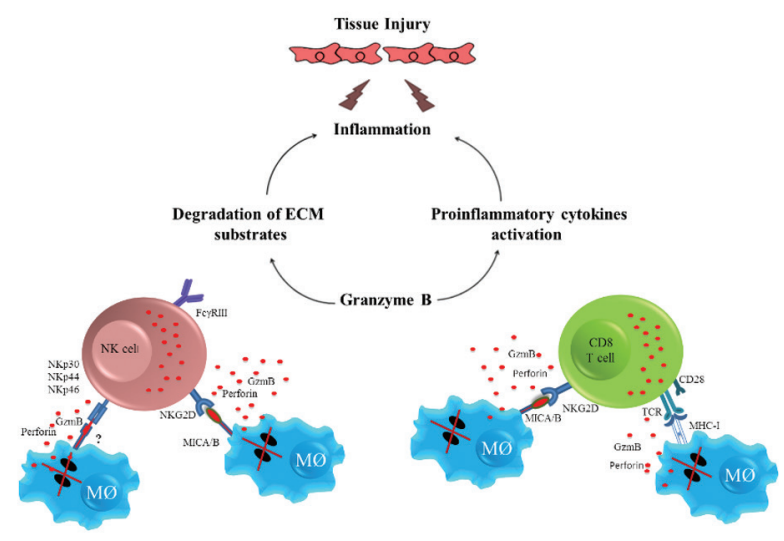

Tissue damage and inflammation mediated by cytotoxic cells in human cutaneous leishmaniasis. With degranulation of natural killer $(\mathrm{NK})$ and $\mathrm{CD} 8+\mathrm{T}$ cells, granzyme B (GzmB) and perforin are released and apoptosis of infected macrophages is induced. Additionally, granzyme B may indirectly induce inflammation through the activation of pro-inflammatory cytokines and degradation of extracellular matrix (ECM) substrates, contributing to tissue damage. *This image has not been previously published. 
jor. In these models, IFN- $\gamma$ produced by CD $8+$ cells was essential for controlling primary infection (Belkaid et al. 2002, Uzonna et al. 2004).

More recently, however, a deleterious effect of CD8+ $\mathrm{T}$ cells, mainly as a result of its cytotoxic activity, has been observed. Experiments using mouse models have contributed to a better understanding of cytotoxicityinduced pathologic responses in CL. Novais et al. (2013) showed the deleterious effect of CD8+ T cells on L. braziliensis-infected mice, in which disease progression and metastasis were associated with the presence of CD8+ T cells and perforin, indicating that the cytotoxic activity of $\mathrm{CD} 8+\mathrm{T}$ cells promotes pathology rather than being a consequence of the disease. The same group showed that memory bystander CD8+ T cells expressing NKG2D and that were not specific to Leishmania antigens were able to infiltrate lesions and contribute to immunopathology in mice infected with $L$. major (Crosby et al. 2014). In another study, mice previously infected with viral or bacterial pathogens and then infected with $L$. major developed significantly larger lesions with an increased number of NKG2D+CD8+ T cells. In this case, depletion of CD8+ T cells, as well as the blockage of NKG2D, decreased the size and severity of lesions, suggesting that the immunopathology observed in LCMV/L. major co-infected mice was dependent on cytotoxic CD8+ T cells induced by NKG2D ligation. In the same study, lesions with a small number CD8+ T cells produced IFN- $\gamma$, whereas high number these cells expressed granzyme B (Crosby et al. 2015). These data indicate that the mechanisms underlying cell death induced by cytotoxic cells contribute to tissue damage instead of parasite killing. In addition, a study by our group indicated that genes associated with cytotoxicity and inflammasome activation were up-regulated in lesions from humans infected with L. braziliensis (Novais et al. 2015). Interestingly, IL-1 $\beta$ production in these lesions was dependent on CD8+ T cell cytotoxicity (Novais et al. 2017). These data support an association between cytotoxic activity and inflammation in cutaneous leishmaniasis. The controversy between a protective versus pathologic role for CD8+ T cells in cutaneous leishmaniasis clearly depends on the parasite dose, as well as the site where the immune response was assessed. Earlier studies investigated the contribution of lymph node and spleen CD8+ T cell to protection, whereas later studies assessing immune response in lesions revealed a deleterious role for $\mathrm{CD} 8+\mathrm{T}$ cells. The different roles for CD8+ T cells in leishmaniasis may reflect heterogeneity in the $\mathrm{CD} 8+\mathrm{T}$ cells population; however, this hypothesis requires further investigation.

The role of NK cells in protection against many pathogens has been a focus of study because of their ability to rapidly produce cytokines and lyse target cells without prior sensitisation. In mouse CL, NK cells have been associated with protection, mainly through the production of IFN- $\gamma$, which is important for macrophage activation (Laskay et al. 1993, Laurenti et al. 1999, Muller et al. 2001). Furthermore, cytotoxic activity and IFN- $\gamma$ production by NK cells was also observed in lymph nodes of self-healing L. major-infected mice (Scharton \& Scott
1993, Bajenoff et al. 2006, Liese et al. 2007). In contrast, NK cells were not necessary for the development of protective immunity against $L$. major, as, in mice lacking NK cells (NK-T+), an efficient Th1 response with high production of IL-12 and IFN- $\gamma$ and control of parasites was observed (Satoskar et al. 1999). In addition, in mice lacking CD4+ T cells, IFN- $\gamma$ production by NK cells was not sufficient to control L. major (Wakil et al. 1998). Although these studies are controversial regarding the requirement for NK cells to control infection, the fact that these cells are potent producers of IFN- $\gamma$ suggest their protective role in cases of CL.

Despite evidence suggesting cytotoxicity as an immune mechanism that contributes to CL pathogenesis, the factors associated with severity of disease still need to be determined.

Concluding remarks - Taken together, the literature shows that NK cells and T lymphocytes not only participate in the control of Leishmania proliferation through IFN- $\gamma$ production but also that these cells may be involved in skin ulceration through tissue disruption as a result of their cytotoxic activity.

\section{ACKNOWLEDGEMENTS}

To Cristiano Franco, for secretarial assistance.

\section{AUTHORS' CONTRIBUTION}

All authors contributed equally to this paper.

\section{REFERENCES}

Afonina IS, Tynan GA, Logue SE, Cullen SP, Bots M, Luthi AU, et al. Granzyme B-dependent proteolysis acts as a switch to enhance the proinflammatory activity of IL-1alpha. Mol Cell. 2011; 44(2): 265-78.

Antonelli LR, Dutra WO, Almeida RP, Bacellar O, Carvalho EM, Gollob KJ. Activated inflammatory T cells correlate with lesion size in human cutaneous leishmaniasis. Immunol Lett. 2005; 101(2): 226-30.

Arias MA, de Bagues MPJ, Aguilo N, Menao S, Hervas-Stubbs S, de Martino A, et al. Elucidating sources and roles of granzymes A and B during bacterial infection and sepsis. Cell Rep. 2014; 8(2): 420-9.

Bacellar O, Lessa H, Schriefer A, Machado P, de Jesus AR, Dutra WO, et al. Up-regulation of Th1-type responses in mucosal leishmaniasis patients. Infect Immun. 2002; 70(12): 6734-40.

Bajenoff M, Breart B, Huang AY, Qi H, Cazareth J, Braud VM, et al. Natural killer cell behavior in lymph nodes revealed by static and real-time imaging. J Exp Med. 2006; 203(3): 619-31.

Barral A, Barral-Netto M, Almeida R, de Jesus AR, Grimaldi Junior G, Netto EM, et al. Lymphadenopathy associated with Leishmania braziliensis cutaneous infection. Am J Trop Med Hyg. 1992; 47(5): 587-92.

Barral A, Guerreiro J, Bomfim G, Correia D, Barral-Netto M, Carvalho EM. Lymphadenopathy as the first sign of human cutaneous infection by Leishmania braziliensis. Am J Trop Med Hyg. 1995; 53(3): 256-9.

Barral Netto M, Barral A, Brodskyn C, Carvalho EM, Reed SG. Cytotoxicity in human mucosal and cutaneous leishmaniasis. Parasite Immunol. 1995; 17(1): 21-8.

Barral Netto M, Brodskyn C, Carvalho EM, Barral A. Human_leishmaniasis/cytokines.bahia.br. Braz J Med Biol Res. 1998; 31(1): 149-55. 
Becker I, Salaiza N, Aguirre M, Delgado J, Carrillo-Carrasco N, Kobeh LG, et al. Leishmania lipophosphoglycan (LPG) activates NK cells through toll-like receptor-2. Mol Biochem Parasitol. 2003; 130(2): 65-74.

Belkaid Y, Von Stebut E, Mendez S, Lira R, Caler E, Bertholet S, et al. $\mathrm{CD} 8+\mathrm{T}$ cells are required for primary immunity in C57BL/6 mice following low-dose, intradermal challenge with Leishmania major. J Immunol. 2002; 168(8): 3992-4000.

Betts MR, Brenchley JM, Price DA, de Rosa SC, Douek DC, Roederer M, et al. Sensitive and viable identification of antigen-specific $\mathrm{CD} 8+\mathrm{T}$ cells by a flow cytometric assay for degranulation. J Immunol Methods. 2003; 281(1-2): 65-78.

Campos TM, Passos ST, Novais FO, Beiting DP, Costa RS, Queiroz $\mathrm{A}$, et al. Matrix metalloproteinase 9 production by monocytes is enhanced by TNF and participates in the pathology of human cutaneous leishmaniasis. PLoS Negl Trop Dis. 2014; 8(11): e3282.

Cardoso TM, Machado A, Costa DL, Carvalho LP, Queiroz A, Machado $\mathrm{P}$, et al. Protective and pathological functions of CD8+ T Cells in Leishmania braziliensis infection. Infect Immun. 2015; 83(3): 898-906.

Carvalho LP, Passos S, Bacellar O, Lessa M, Almeida RP, Magalhães A, et al. Differential immune regulation of activated T cells between cutaneous and mucosal leishmaniasis as a model for pathogenesis. Parasite Immunol. 2007; 29(5): 251-8.

Castellano LR, Filho DC, Argiro L, Dessein H, Prata A, Dessein A, et al. Th1/Th2 immune responses are associated with active cutaneous leishmaniasis and clinical cure is associated with strong interferon-gamma production. Hum Immunol. 2009; 70(6): 383-90.

Costa JD, de Melo ACN, Vermelho AB, Meirelles MN, Porrozzi R. In vitro evidence for metallopeptidase participation in hepatocyte damage induced by Leishmania chagasi-infected macrophages. Acta Trop. 2008; 106(3): 175-83.

Crosby EJ, Clark M, Novais FO, Wherry EJ, Scott P. Lymphocytic choriomeningitis virus expands a population of NKG2D+CD8+ $\mathrm{T}$ cells that exacerbates disease in mice coinfected with Leishmania major. J Immunol. 2015; 195(7): 3301-10.

Crosby EJ, Goldschmidt MH, Wherry EJ, Scott P. Engagement of NKG2D on bystander memory CD $8 \mathrm{~T}$ cells promotes increased immunopathology following Leishmania major infection. PLoS Pathog. 2014; 10(2): e1003970.

Da-Cruz AM, Bittar R, Mattos M, Oliveira-Neto MP, Nogueira R, Pinho-Ribeiro $\mathrm{V}$, et al. T-cell-mediated immune responses in patients with cutaneous or mucosal leishmaniasis: long-term evaluation after therapy. Clin Diagn Lab Immunol. 2002; 9(2): 251-6.

Da-Cruz AM, Conceição-Silva F, Bertho AL, Coutinho SG. Leishmania-reactive CD4+ and CD8+ T cells associated with cure of human cutaneous leishmaniasis. Infect Immun. 1994; 62(6): 2614-8.

Dantas ML, Oliveira JC, Carvalho L, Passos ST, Queiroz A, Machado P, et al. CD8+ T cells in situ in different clinical forms of human cutaneous leishmaniasis. Rev Soc Bras Med Trop. 2013; 46(6): 728-34.

D’Oliveira Jr A, Machado P, Bacellar O, Cheng LH, Almeida RP, Carvalho EM. Evaluation of IFN-gamma and TNF-alpha as immunological markers of clinical outcome in cutaneous leishmaniasis. Rev Soc Bras Med Trop. 2002; 35(1): 7-10.

Falcão SA, Weinkopff T, Hurrell BP, Celes FS, Curvelo RP, Prates DB, et al. Exposure to Leishmania braziliensis triggers neutrophil activation and apoptosis. PLoS Negl Trop Dis. 2015; 9(3): e0003601.

Faria DR, Gollob KJ, Barbosa Jr J, Schriefer A, Machado PR, Lessa H, et al. Decreased in situ expression of interleukin-10 receptor is correlated with the exacerbated inflammatory and cytotoxic responses observed in mucosal leishmaniasis. Infect Immun. 2005; 73(12): 7853-9.
Faria DR, Souza PE, Duraes FV, Carvalho EM, Gollob KJ, Machado $\mathrm{PR}$, et al. Recruitment of CD8(+) T cells expressing granzyme A is associated with lesion progression in human cutaneous leishmaniasis. Parasite Immunol. 2009; 31(8): 432-9.

Ferraz R, Cunha CF, Gomes-Silva A, Schubach AO, Pimentel MI, Lyra $\mathrm{MR}$, et al. Apoptosis and frequency of total and effector CD8+ T lymphocytes from cutaneous leishmaniasis patients during antimonial therapy. BMC Infect Dis. 2015; 19(15): 74.

Ferraz R, Cunha CF, Pimentel MIF, Lyra MR, Pereira-da-Silva T, Schubach AO, et al. CD3+CD4negCD8neg (double negative) T lymphocytes and NKT cells as the main cytotoxic-related-CD107a+ cells in lesions of cutaneous leishmaniasis caused by Leishmania (Viannia) braziliensis. Parasit Vectors. 2017; 10(1): 219.

Follador I, Araujo C, Bacellar O, Araujo CB, Carvalho LP, Almeida $\mathrm{RP}$, et al. Epidemiologic and immunologic findings for the subclinical form of Leishmania braziliensis infection. Clin Infect Dis. 2002; 34(11): E54-8.

Gaze ST, Dutra WO, Lessa M, Lessa H, Guimarães LH, Jesus AR, et al. Mucosal leishmaniasis patients display an activated inflammatory T-cell phenotype associated with a nonbalanced monocyte population. Scand J Immunol. 2006; 63(1): 70-8.

Gorak PM, Engwerda CR, Kaye PM. Dendritic cells, but not macrophages, produce IL-12 immediately following Leishmania donovani infection. Eur J Immunol. 1998; 28(2): 687-95.

Hiebert PR, Granville DJ. Granzyme B in injury, inflammation, and repair. Trends Mol Med. 2012; 18(12): 732-41.

Hill JO, Awwad M, North RJ. Elimination of CD4+ suppressor T cells from susceptible BALB/c mice releases CD8+ T lymphocytes to mediate protective immunity against Leishmania. J Exp Med. 1989; 169(5): 1819-27.

Hoves S, Trapani JA, Voskoboinik I. The battlefield of perforin/granzyme cell death pathways. J Leukoc Biol. 2010; 87(2): 237-43.

Huber M, Timms E, Mak TW, Rollinghoff M, Lohoff M. Effective and long-lasting immunity against the parasite Leishmania major in CD8-deficient mice. Infect Immun. 1998; 66(8): 3968-70.

Jordan KA, Hunter CA. Regulation of CD8+ T cell responses to infection with parasitic protozoa. Exp Parasitol. 2010; 126(3): 318-25.

Kaye P, Scott P. Leishmaniasis: complexity at the host-pathogen interface. Nat Rev Microbiol. 2011; 9(8): 604-15.

Khan IA, Smith KA, Kasper LH. Induction of antigen-specific human cytotoxic T cells by Toxoplasma gondii. J Clin Invest. 1990; 85(6): 1879-86.

Lanier LL. NK cell recognition. Annu Rev Immunol. 2005; 23: 225-74.

Laskay T, Rollinghoff M, Solbach W. Natural killer cells participate in the early defense against Leishmania major infection in mice. Eur J Immunol. 1993; 23(9): 2237-41.

Laurenti MD, Gidlund M, Ura DM, Sinhorini IL, Corbett CE, Goto $\mathrm{H}$. The role of natural killer cells in the early period of infection in murine cutaneous leishmaniasis. Braz J Med Biol Res. 1999; 32(3): 323-5.

Lemos MP, Esquivel F, Scott P, Laufer TM. MHC class II expression restricted to CD8alpha+ and CD11b+ dendritic cells is sufficient for control of Leishmania major. J Exp Med. 2004; 199(5): 725-30.

Lieke T, Nylen S, Eidsmo L, McMaster WR, Mohammadi AM, Khamesipour A, et al. Leishmania surface protein gp63 binds directly to human natural killer cells and inhibits proliferation. Clin Exp Immunol. 2008; 153(2): 221-30. 
Lieke T, Nylen S, Eidsmo L, Schmetz C, Berg L, Akuffo H. The interplay between Leishmania promastigotes and human Natural Killer cells in vitro leads to direct lysis of Leishmania by NK cells and modulation of NK cell activity by Leishmania promastigotes. Parasitology. 2011; 138(14): 1898-1909.

Liese J, Schleicher U, Bogdan C. TLR9 signaling is essential for the innate NK cell response in murine cutaneous leishmaniasis. Eur J Immunol. 2007; 37(12): 3424-34.

Machado P, Kanitakis J, Almeida R, Chalon A, Araujo C, Carvalho EM. Evidence of in situ cytotoxicity in American cutaneous leishmaniasis. Eur J Dermatol. 2002; 12(5): 449-51.

Maretti-Mira AC, de Oliveira Neto MP, da Cruz AM, de Oliveira MP, Craft N, Pirmez C. Therapeutic failure in American cutaneous leishmaniasis is associated with gelatinase activity and cytokine expression. Clin Exp Immunol. 2011a; 163(2): 207-14.

Maretti-Mira AC, Rodrigues KMP, de Oliveira Neto MP, Pirmez C, Craft N. MMP-9 activity is induced by Leishmania braziliensis infection and correlates with mucosal leishmaniasis. Acta Trop. 2011b; 119(2-3): 160-4.

Metkar SS, Menaa C, Pardo J, Wang B, Wallich R, Freudenberg M, et al. Human and mouse granzyme A induce a proinflammatory cytokine response. Immunity. 2008; 29(5): 720-33.

Montoya JG, Lowe KE, Clayberger C, Moody D, Do D, Remington JS, et al. Human CD4+ and CD8+ T lymphocytes are both cytotoxic to Toxoplasma gondii-infected cells. Infect Immun. 1996; 64(1): 176-81.

Muller I, Pedrazzini T, Kropf P, Louis J, Milon G. Establishment of resistance to Leishmania major infection in susceptible BALB/c mice requires parasite-specific CD8+ T cells. Int Immunol. 1991; 3(6): 587-97.

Muller K, van Zandbergen G, Hansen B, Laufs H, Jahnke N, Solbach $\mathrm{W}$, et al. Chemokines, natural killer cells and granulocytes in the early course of Leishmania major infection in mice. Med Microbiol Immunol. 2001; 190(1-2): 73-6.

Naouar I, Boussoffara T, Ahmed MB, Hmida NB, Gharbi A, Gritli S, et al. Involvement of different CD4(+) T cell subsets producing granzyme B in the immune response to Leishmania major antigens. Mediators Inflamm. 2014; 2014: 636039.

Novais FO, Carvalho AM, Clark ML, Carvalho LP, Beiting DP, Brodsky IE, et al. CD8+ T cell cytotoxicity mediates pathology in the skin by inflammasome activation and IL-1beta production. PLoS Pathog. 2017; 13(2): e1006196.

Novais FO, Carvalho LP, Graff JW, Beiting DP, Ruthel G, Roos DS, et al. Cytotoxic T cells mediate pathology and metastasis in cutaneous leishmaniasis. PLoS Pathog. 2013; 9(7): e1003504.

Novais FO, Carvalho LP, Passos S, Roos DS, Carvalho EM, Scott P, et al. Genomic profiling of human Leishmania braziliensis lesions identifies transcriptional modules associated with cutaneous immunopathology. J Invest Dermatol. 2015; 135(1): 94-101.

Novais FO, Santiago RC, Bafica A, Khouri R, Afonso L, Borges VM, et al. Neutrophils and macrophages cooperate in host resistance against Leishmania braziliensis infection. J Immunol. 2009; 183(12): 8088-98.

Omoto Y, Yamanaka K, Tokime K, Kitano S, Kakeda M, Akeda T, et al. Granzyme B is a novel interleukin-18 converting enzyme. J Dermatol Sci. 2010; 59(2): 129-35.

Overath P, Harbecke D. Course of Leishmania infection in beta 2-microglobulin-deficient mice. Immunol Lett. 1993; 37(1): 13-7.

Peters NC, Egen JG, Secundino N, Debrabant A, Kimblin N, Kamhawi $\mathrm{S}$, et al. In vivo imaging reveals an essential role for neutro- phils in leishmaniasis transmitted by sand flies. Science. 2008; 321(5891): 970-4.

Pipkin ME, Lieberman J. Delivering the kiss of death: progress on understanding how perforin works. Curr Opin Immunol. 2007; 19(3): 301-8.

Pirmez C, Yamamura M, Uyemura K, Paes-Oliveira M, ConceiçãoSilva F, Modlin RL. Cytokine patterns in the pathogenesis of human leishmaniasis. J Clin Invest. 1993; 91(4): 1390-5.

Purner MB, Berens RL, Nash PB, van Linden A, Ross E, Kruse C, et al. CD4-mediated and CD8-mediated cytotoxic and proliferative immune responses to Toxoplasma gondii in seropositive humans. Infect Immun. 1996; 64(10): 4330-8.

Ribeiro-de-Jesus A, Almeida RP, Lessa H, Bacellar O, Carvalho EM. Cytokine profile and pathology in human leishmaniasis. Braz J Med Biol Res. 1998; 31(1): 143-8.

Ribeiro-Gomes FL, Moniz-de-Souza MC, Alexandre-Moreira MS, Dias WB, Lopes MF, Nunes MP, et al. Neutrophils activate macrophages for intracellular killing of Leishmania major through recruitment of TLR4 by neutrophil elastase. J Immunol. 2007; 179(6): 3988-94

Ribeiro-Gomes FL, Otero AC, Gomes NA, Moniz-de-Souza MC, Cysne-Finkelstein L, Arnholdt AC, et al. Macrophage interactions with neutrophils regulate Leishmania major infection. J Immunol. 2004; 172(7): 4454-62.

Ribeiro-Gomes FL, Peters NC, Debrabant A, Sacks DL. Efficient capture of infected neutrophils by dendritic cells in the skin inhibits the early anti-leishmania response. PLoS Pathog. 2012; 8(2): e1002536.

Ruiz JH, Becker I. CD8 cytotoxic T cells in cutaneous leishmaniasis. Parasite Immunol. 2007; 29(12): 671-8.

Saldanha MG, Queiroz A, Machado PRL, de Carvalho LP, Scott P, de Carvalho Filho EM, et al. Characterization of the histopathologic features in patients in the early and late phases of cutaneous leishmaniasis. Am J Trop Med Hyg. 2017; 96(3): 645-52.

Santos C, Attarha S, Saini RK, Boaventura V, Costa J, Khouri R, et al. Proteome profiling of human cutaneous leishmaniasis lesion. J Invest Dermatol. 2015; 135(2): 400-10.

Santos CS, Boaventura V, Cardoso CR, Tavares N, Lordelo MJ, Noronha A, et al. CD8(+) granzyme $\mathrm{B}(+)$-mediated tissue injury vs. CD4(+)IFNgamma(+)-mediated parasite killing in human cutaneous leishmaniasis. J Invest Dermatol. 2013; 133(6): 1533-40.

Satoskar AR, Stamm LM, Zhang X, Satoskar AA, Okano M, Terhorst $\mathrm{C}$, et al. Mice lacking NK cells develop an efficient Th1 response and control cutaneous Leishmania major infection. J Immunol. 1999; 162(11): 6747-54.

Scapini P, Lapinet-Vera JA, Gasperini S, Calzetti F, Bazzoni F, Cassatella MA. The neutrophil as a cellular source of chemokines. Immunol Rev. 2000; 177: 195-203.

Scharton TM, Scott P. Natural killer cells are a source of interferon gamma that drives differentiation of $\mathrm{CD} 4+\mathrm{T}$ cell subsets and induces early resistance to Leishmania major in mice. J Exp Med. 1993; 178(2): 567-77.

Schriefer A, Guimarães LH, Machado PR, Lessa M, Lessa HA, Lago $\mathrm{E}$, et al. Geographic clustering of leishmaniasis in northeastern Brazil. Emerg Infect Dis. 2009; 15(6): 871-6.

Scott P, Natovitz P, Coffman RL, Pearce E, Sher A. Immunoregulation of cutaneous leishmaniasis. T cell lines that transfer protective immunity or exacerbation belong to different $\mathrm{T}$ helper subsets and respond to distinct parasite antigens. J Exp Med. 1988; 168(5): 1675-84. 
Sower LE, Klimpel GR, Hanna W, Froelich CJ. Extracellular activities of human granzymes. I. Granzyme A induces IL6 and IL8 production in fibroblast and epithelial cell lines. Cell Immunol. 1996; 171(1): 159-63.

Thalhofer CJ, Chen Y, Sudan B, Love-Homan L, Wilson ME. Leukocytes infiltrate the skin and draining lymph nodes in response to the protozoan Leishmania infantum chagasi. Infect Immun. 2011; 79(1): 108-17.

Thiery J, Keefe D, Boulant S, Boucrot E, Walch M, Martinvalet D, et al. Perforin pores in the endosomal membrane trigger the release of endocytosed granzyme B into the cytosol of target cells. Nat Immunol. 2011; 12(8): 770-7.

Titus RG, Milon G, Marchal G, Vassalli P, Cerottini JC, Louis JA. Involvement of specific Lyt-2+ T cells in the immunological control of experimentally induced murine cutaneous leishmaniasis. Eur J Immunol. 1987; 17(10): 1429-33.

Tomlinson ML, Garcia-Morales C, Abu-Elmagd M, Wheeler GN. Three matrix metalloproteinases are required in vivo for macrophage migration during embryonic development. Mech Dev. 2008; 125(11-12): 1059-70.

Trapani JA, Smyth MJ. Functional significance of the perforin/granzyme cell death pathway. Nat Rev Immunol. 2002; 2(10): 735-47.
Trapani JA. Granzymes: a family of lymphocyte granule serine proteases. Genome Biol. 2001; 2(12): reviews3014.

Unger A, O’Neal S, Machado PR, Guimarães LH, Morgan DJ, Schriefer A, et al. Association of treatment of American cutaneous leishmaniasis prior to ulcer development with high rate of failure in northeastern Brazil. Am J Trop Med Hyg. 2009; 80(4): 574-9.

Uzonna JE, Joyce KL, Scott P. Low dose Leishmania major promotes a transient $\mathrm{T}$ helper cell type 2 response that is down-regulated by interferon gamma-producing CD8+ T cells. J Exp Med. 2004; 199(11): 1559-66.

Wakil AE, Wang ZE, Ryan JC, Fowell DJ, Locksley RM. Interferon gamma derived from $\mathrm{CD} 4(+) \mathrm{T}$ cells is sufficient to mediate $\mathrm{T}$ helper cell type 1 development. J Exp Med. 1998; 188(9): 1651-6.

Wang ZE, Reiner SL, Hatam F, Heinzel FP, Bouvier J, Turck CW, et al. Targeted activation of CD8 cells and infection of beta 2-microglobulin-deficient mice fail to confirm a primary protective role for CD8 cells in experimental leishmaniasis. J Immunol. 1993; 151(4): 2077-86.

Waterhouse NJ, Sutton VR, Sedelies KA, Ciccone A, Jenkins M, Turner SJ, et al. Cytotoxic T lymphocyte-induced killing in the absence of granzymes A and B is unique and distinct from both apoptosis and perforin-dependent lysis. J Cell Biol. 2006; 173(1): 133-44.

Watzl C. The NKG2D receptor and its ligands-recognition beyond the "missing self"? Microbes Infect. 2003; 5(1): 31-7. 